\title{
Kreatiewe prediking as die sigbaarmaking van ou en nuwe dinge en die verryking van die luisteraksie deur middel van preekgesprekke
}

\begin{abstract}
Author:
Ferdi P. Kruger ${ }^{1}$

\section{Affiliation:}

${ }^{1}$ Faculty of Theology, North-West University, Potchefstroom Campus, South Africa

\section{Correspondence to:}

Ferdi Kruger

Email:

ferdikruger4@gmail.com

\section{Postal address:}

Strauss Avenue 1, Van der Hoff Park, Potchefstroom 2531, South Africa

\section{Dates:}

Received: 31 July 2013

Accepted: 21 Nov. 2013

Published: 22 July 2014

How to cite this article: Kruger, F.P., 2014, 'Kreatiewe prediking as die sigbaarmaking van ou en nuwe dinge en die verryking van die luisteraksie deur middel van preekgesprekke', In die Skriflig 48(1), Art. \#1704, 11 pages. http:// dx.doi.org/10.4102/ids. v48i1.1704
\end{abstract}

\section{Copyright:}

(C) 2014. The Authors.

Licensee: AOSIS OpenJournals. This work is licensed under the Creative Commons Attribution License.
Uit die kerklike praksis blyk dat goed bedoelde prediking wat op 'n biddende wyse gelewer word, meermale skipbreuk ly as gevolg van 'n vervelige aanbieding waarna die hoorders moet luister. Tussen die blote hoor van en 'n diepgaande en kreatiewe manier van luister na die prediking bestaan 'n groot verskil. Predikers moet dus oefen en hulself toerus om in hulle preekvoorbereiding en preeklewering meer kreatief gerig te wees. Kreatiewe prediking open nuwe en dinamiese perspektiewe vir die hoorders. In die lig hiervan word die volgende navorsingsvraag as die doel van hierdie navorsing geformuleer: In hoe ' $n$ mate rus predikers hulle hoorders op ' $n$ kreatiewe manier toe om kreatief deel te neem en na die prediking te luister sodat dít wat gesê en bedoel word, die hoorders se lewe kan beïnvloed? Ten einde hierdie navorsingsvraag te beantwoord, word die probleemveld uit verskillende praktiesteologiese invalshoeke verken en metateoretiese perspektiewe word uit die velde van die Sosiale Psigologie en die Kunsgeskiedenis ontgin. Hierdeur word insig ten opsigte van die vorming en die funksionering van kreatiwiteit verkry. Perspektiewe uit 2 Samuel 17 en Matteus 13:13-15, 52 word verken. Daar word tot die gevolgtrekking gekom dat persepsies oor die prediker en die prediking verlammend kan inwerk en selfs daartoe aanleiding kan gee dat hoorders die kerk verlaat. Die bevinding is dat dialoog voor die preeklewering die dialogiese gerigtheid van die prediking as deel van die liturgie van die gemeente, asook die preekgesprekke na afloop van die prediking, daartoe kan meewerk dat verkeerde persepsies reggestel word en dat 'n gemeente 'n pratende gemeente word wat deur diepgaande kommunikasie gevoed word.

Creative preaching as visualisation of old and new things with particular reference to ecclesiastical discourses as enrichment of the act of listening. Ecclesiastical praxis indicates that preaching faces obstacles caused by the dreariness of sermons, regardless of the good intentions of preachers. There is a vast difference between hearing sermons and listening to sermons in a creative manner. Preachers should equip themselves to be more creative in the preparation and delivery of sermons. Creative preaching opens up new perspectives to hearers. In the light of this problematic praxis, the following research question has been formulated: To what extent do preachers equip their listeners in a dialogue situation to listen creatively in a profound manner with the objective to see clearly what the Word of God demands of them? In order to address this research question, the problem is investigated by taking into account the present Practical Theological vantage points concerning this field and by trying to get a grasp on metatheoretical perspectives from the fields of Social Psychology and the History of Art. The author investigates the challenging process of creative preaching as well as the importance of equipping hearers in becoming participants in the preparation of sermons through the process of ecclesiastical and sermon discussions. Perspectives from 2 Samuel 17 and Matthew 13:13-15, 52 will be explored with regard to the role of creativity in preaching. The conclusion is reached that a lack in creative preaching and commitment to the act of preaching are indeed endangering this ecclesiastical praxis. It may even be the cause of listeners leaving the church. Preachers should utilise creativity in preparing their sermons and should also focus on the custom of sermon discussions before and after delivering their sermons. In addition, preachers should endeavour to stimulate feedback of the sermons, for in this way fallacious views of reality could be rectified. Congregations should become discussant communities nurtured through profound communication.

\section{Inleiding}

Die funksionering van die mens se brein word as ' $n$ kunsgalery beskou waarin verbeelding ' $n$ vername rol speel. Die prediking staan, in die lig hiervan, voor die uitdaging om hoorders die 
bekende werklikheid uit 'n nuwe perspektief te laat aanskou (Wiersbe 2006:24). Dit is 'n moeilike uitdaging, aangesien gedagtes teen ongeveer 300 kilometer per sekonde deur 'n mens se brein beweeg en jy bykans voortdurend besig is om inligting te verwerk (Joubert 2003:7-9). Stott (1996:52) rig 'n pleidooi daarvoor dat hoorders hulle denke optimaal moet inspan wanneer hulle na preke luister en dat predikers die hoorders op ' $n$ vars en prikkelende wyse hierin moet begelei. Vroeg reeds het Craddock (1985:27-30) dit benadruk dat die prediking as kreatiewe handeling dit ten doel het om hoorders na hulle asem te laat snak, sodat hulle ook 'aha!' kan uitroep wanneer hulle tot nuwe insigte kom.Volgens Pieterse (2001:78) woon hoorders immers die eredienste by om die Woord van God te hoor en dit veronderstel dat in die voorbereiding en lewering van preke kreatiewe insigte aanwesig moet wees. Die primêre vertrekpunt in hierdie artikel is dat deeglike eksegese altyd ten grondslag van die prediking moet lê, want sonder die insig deur die eksegese het predikers geen boodskap om te bring nie. Sonder 'n kreatiewe preekoordrag sal die prediking onder die erediens egter vir die hoorders ook bloot verveling meebring (Gordon 2009:29). Woodley (2012:127) maak 'n sterk saak daarvoor uit dat verveling by hoorders onder die prediking 'n belangrike saak is wat die aandag van die predikers behoort te geniet. Die prediking moet dus daarop fokus om die hoorders te inspireer om die regte dinge te doen. Piper (2012:6) ondersteun Woodley en benadruk dat predikers moeite moet doen om die grootheid van God inspirerend deur die prediking te bly kommunikeer.

In die lig van bogenoemde stellings blyk dat predikers dikwels neig om hulleself nie as kreatief genoeg te beskou nie en dit as 'n verskoning misbruik om nie kreatief in die prediking te wees nie. Wiersbe (2006:290) toon statisties uit navorsing aan dat mense slegs $2 \%$ so kreatief op 40 jaar is as wat hulle op 5 jaar was. 'n Moontlike rede hiervoor is die sterk kognitiewe inslag in die onderwys en die tersiêre onderrig. Predikers moet volgens Cilliers (2009:9-12) dus meer moeite met die performatiewe karakter van die prediking doen. Dit behels dat predikers in hulle omgang met die teks God se bedoeling (intensie) met die teks deeglik moet navors, sodat hulle dit ook op 'n kreatiewe wyse aan die hoorders kan kommunikeer sodat daardeur 'n verandering in hulle lewe kan plaasvind. Hierdeur word 'n relevante navorsingsveld in die Praktiese Teologie aangeraak wat onder andere beklemtoon dat mense in beelde dink, selfs al gebruik hulle woorde om te skryf en te praat (vgl. Brueggemann 2009:21; Grözinger 2002:55; Long 2005:199; Vos 2007:24-25; Wiersbe 2006:23-24; Troeger 2007:78).

Teen hierdie agtergrond wil dit voorkom asof die prediking steeds met die versugting na groter kreatiwiteit in die voorbereiding en lewering daarvan gekonfronteer word. Die verskillende aksente wat tans op die prediking geplaas word, byvoorbeeld etiese prediking, profetiese prediking en eskatologiese prediking, beklemtoon moontlik 'n groter kreatiwiteit by die predikers sodat die hoor van die Woord kan uitkom by die sien van die visie wat God op die werklikheid het (vgl. De Gruchy 2011:385; Koopman 2010:385; Pieterse
2001:82; Tubbs-Tisdale 2010:10). In hierdie artikel sal op die kontoere van die kreatiewe prediking gefokus word, spesifiek ten opsigte van die ontwikkeling van die gedagtes van die preek wat hoorders in staat stel om die realiteit hiervan te aanskou. Die doel van hierdie artikel is om aan te toon dat die predikers opnuut op die voorreg om te kan preek, moet fokus, maar dat hierdie voorreg ook 'n verantwoordelikheid meebring om die hoorders op 'n kreatiewe wyse met hulle saam te neem.

In hierdie artikel word aansluiting gevind by die metodologiese lyne van 'n reflektiewe balans wat Osmer (2010:3) vir die prakties-teologiese navorsing onderskei het. Osmer (2010:3) onderskei in sy besinning oor 'n hermeneutiese spiraal in 'n prakties-teologiese ondersoek vier hooflyne:

- 'n Beskrywend-empiriese ondersoek waarin die navorser inligting versamel om die probleemveld binne die praksis beter te begryp.

- 'n Interpretatiewe ondersoek waardeur die navorser poog om te analiseer waarom sekere handelings binne die probleemveld geskied.

- 'n Normatiewe ondersoek waarin normatiewe vrae uit ander velde van die Teologie gestel word.

- 'n Pragmatiese ondersoek waarin die navorser poog om perspektiewe daar te stel om die problematiese praksis te herstel.

Die ondersoek geskied in vier fases. Fase een bied 'n beskrywende refleksie van navorsing wat oor hierdie probleemveld in die Praktiese Teologie gedoen is. Op 'n interpretatiewe wyse word in fase twee 'n verkennende ondersoek vanuit die vakgebiede van die Kunsgeskiedenis en die Sosiale Psigologie gedoen oor die feit dat gebrekkige kreatiwiteit 'n problematiese praksis bewerkstellig. 'n Intradissiplinêre gesprek word op hierdie wyse met die Kunsgeskiedenis en Sosiale Psigologie gevoer. In die derde fase word 'n normatiewe ondersoek gedoen waartydens basisteoretiese perspektiewe uit sentrale Skrifgedeeltes ontgin en ontleed word. Praktyk-teoretiese perspektiewe word in die vierde fase van die ondersoek ontgin en kan moontlik daartoe lei dat predikers opnuut weer moeite daarmee sal maak om met hoorders in gesprek te tree om sodoende kreatiwiteit te versterk.

\section{'n Beskrywend-empiriese ondersoek van die praksis rakende verbeelding en kreatiwiteit}

In hierdie onderafdeling word die problematiese praksis oorsigtelik aan die hand van 'n beperkte ondersoek na beskikbare literatuur verken. Die kontoere van navorsing op hierdie gebied word aangetoon, asook die noodsaak van die bepaalde invalshoek van hierdie navorsing.

\section{Navorsing wat die rol van verbeelding in die prediking ondersoek}

Gedurende die afgelope agt jaar is die belangrike rol wat verbeelding (nie fantasie nie) in die prediking moet speel deur onder andere die volgende outeurs beklemtoon: 
- In sy navorsing plaas Mitchell (2009:195-197) die prediking teen die agtergrond van die visuele werklikheid en toon aan dat die predikers en die hoorders vanweë blootstelling aan die radio, televisie en advertensies waarin allerlei beelde en drome aan hulle voorgehou word, met 'n uitdaging te make het betreffend die prediking onder die erediens. In die multimedia waaraan die hoorders blootgestel word, het hulle voortdurend met beelde en kommunikators te make wat mekaar afwissel. In die prediking word die hoorders genoodsaak om vir 'n geruime tyd te fokus op dít wat die predikers verkondig.

- Brueggemann (2009:53) benadruk op sy beurt die multidimensionaliteit van die Bybel wat in die prediking gebruik moet word om aan die hoorders 'n nuwe uitkyk en visie op hulle werklikheid te bied. Daar moet dus 'n kreatiewe verbeelding op grond van die teks daargestel word. Juis daar waar kreatiwiteit ontbreek, tree verveling in.

- Wiersbe (2006:290) benadruk weer dat verbeelding en kreatiwiteit deel van 'n geesvervulde lewe uitmaak. Indien die hoorders in hulle denke oor 'n idee van 'n kunsgalery met 'n verskeidenheid prente daarin beskik, moet die prediking die hoorders help om hiermee kreatief om te gaan.

- Long (2005:198) toon hieromtrent aan dat die prediking van abstraksie bevry moet word. Prediking wat nie duidelik aantoon dat God op die werklikheid van die hoorders se lewe 'n reg het nie, kan nie daarop aanspraak maak dat dit prediking is nie.

\section{Navorsing wat die rol van kreatiwiteit in die prediking benadruk}

Die afgelope 11 jaar het veral die volgende outeurs die belangrikheid van kreatiwiteit benadruk:

- Engemann (2002:38) toon aan dat kreatiewe prediking die ruimte vir hoorders moet skep om verder met die preek te kan omgaan, sodat hulle daders van die Woord kan word. Kreatiewe prediking skep en antisipeer 'n nuwe wêreld waarin God se teenwoordigheid vooropstaan.

- Cilliers (2004:201) wys in sy navorsing op die skeppende (kreatiewe) krag van die prediking. Hierdeur toon hy aan dat kreatiwiteit iets is wat in die predikers gebeur, maar terselfdertyd ook iets is wat aangeleer moet word. Dit geskied in die vier fases van kreatiwiteit, naamlik die voorbereiding van die preek, die ontwikkelingsfase van die preek, die sekerheid oor die teks en die preeklewering.

- Vos (2007:25) benadruk op sy beurt die rol wat woorde in die prediking moet speel. Hy plaas die begrippe kreatiwiteit en fantasie teenoor mekaar en toon aan dat kreatiwiteit iets anders is as fantasie wat die werklikheid ontken. Kreatiwiteit wil juis die werklikheid van die hoorders se lewe verryk.

- Avery en Grobbel (2009:270) bevind in 'n empiriese studie dat hoorders 'n skuldgevoel het en hulself verwyt oor die gebrekkige impak wat die prediking op hulle lewe het. 'n Pertinente rede wat die hoorders aangetoon het, is dat hulle nie meer duidelikheid oor die taak en rol van die aanspraak van die prediking in hulle lewe het nie.
Bykans 80\% van die respondente het aangetoon dat hulle 'n behoefte het dat die prediking op 'n kreatiewe wyse oor die brandpunte van die dag moet handel.

\section{Navorsing wat kreatiwiteit in die vorming van preke betrek}

In prakties-teologiese navorsing is eiesoortige aksente op die prediking geplaas wat nog 'n groter invloed in die werklikheid van die hoorders se lewe moet uitoefen. Dit is opmerklik dat die outeurs dit ook bepleit dat daar op 'n nuwe manier met die werklikheid in die prediking omgegaan moet word. Die volgende navorsing dien as bewys hiervan:

- Long (2009:117-118) benadruk die belangrikheid daarvan dat die inhoud van die prediking en die struktuur daarvan nie twee aparte fases is nie. Predikers moet moeite doen om die gepaste vorm vir elke preek te skep om sodoende optimaal duidelik te kommunikeer.

- Robinson (2001:166) onderstreep die noodsaak dat die preekinleidings onthullend van aard moet wees. Die predikers se gesindhede word op hierdie wyse geopenbaar en juis tydens hierdie preekinleidings besluit die hoorders alreeds of hulle na die prediker gaan luister, of nie.

- Vos (1996:259-269) plaas die klem op kreatiwiteit in die ontwerp van die preekinleidings en die preekontwikkeling wat daarop volg.

Uit bogenoemde beredenering blyk dat die praksis waarin die prediking geskied, wel verdere besinning noodsaak. Alhoewel heelwat navorsing reeds oor kreatiewe prediking gedoen is, wil dit lyk asof hierdie aspek verdere aandag verdien deur klem op die wisselwerking tussen die Kunsgeskiedenis en die Sosiale Psigologie aan die een kant te plaas en die normatiewe openbaring uit die Skrif aan die ander kant, sodat praktykteoretiese merkers eventueel aangestip kan word.

\section{Metateoretiese waarnemings ten opsigte van die rol wat kreatiwiteit speel}

Erkenning word in hierdie artikel aan die intradissiplinêre benadering ten opsigte van die aangrensende sosiale wetenskappe gegee (Cartledge 2003:15). In hierdie opsig onderstreep De Wet (2011:2) die belangrikheid van metateoretiese verkenning as een van die belangrikste en moontlik die eerste stap ten opsigte van die verantwoording wat hierdie veld van ondersoek betref. Om die doel van hierdie artikel te bereik, word vervolgens in gesprek getree met die vakgebiede van die Kunsgeskiedenis en die Sosiale Psigologie. In albei hierdie vakgebiede is alreeds in die verlede indringend oor die begrip kreatiwiteit navorsing gedoen en hoe sodanige kreatiwiteitsproses daar uitsien. Die keuse van die Kunsgeskiedenis as een van die gespreksgenote kan daaraan toegeskryf word dat kunstenaars, in hulle skeppingsproses, met kreatiewe probleemoplossings vorendag moet kom vir spesifieke probleme waarmee hulle te kampe kry (Honour \& Flemming 2002:12; Stewart 2008:3). 
Kuns is volgens Honour en Flemming (2002:11) ook 'n kommunikasiemiddel waarin uitlatings met 'n didaktiese gerigtheid gemaak word. In die Praktiese Teologie heers wye konsensus met Firet (1987:260) wat aandui dat praktiesteologiese navorsing met die kommunikatiewe handelings in diens van die evangelie te make het. Juis vanweë die kommunikatiewe raakveld van kommunikasie en kreatiwiteit kan 'n intradissiplinêre gesprek met die vakgebied van die Kunsgeskiedenis van waarde wees. In die Sosiale Psigologie word die wyse waarop individue se gedrag deur ander mense beïnvloed word, ondersoek (Louw \& Edwards 1998:679). In die Praktiese Teologie word onder andere oor die handelings binne gemeentes besin en juis daarom kan 'n gesprek met die Sosiale Psigologie tot voordeel van hierdie spesifieke navorsing strek.

\section{Metateoretiese perspektiewe op kreatiwiteit vanuit die Kunsgeskiedenis}

Grözinger (2002:169) is oortuig dat die Kunsgeskiedenis 'n ondersteunende rol in prakties-teologiese navorsing kan speel, aangesien dit daartoe kan bydra dat hoorders die werklikheid waarbinne hulle leef hierdeur kan herken. Volgens Cilliers (2004:18) het die Kunsgeskiedenis ook vantevore as katarsis vir die bekendmaking van die dimensies van die geestelike lewe gedien. Reierson (1988:7-10) toon aan dat kuns 'n vermoë het om godsdienstige betekenis en vrae te kommunikeer. Die volgende aspekte uit die navorsingsveld van die Kunsgeskiedenis verdien nadere aandag:

\section{Wat is kreatiwiteit?}

Edwards (2008:7) toon aan dat die begrippe kreatiwiteit en kuns oor die jare byna sinoniem met mekaar geword het, dalk vanweë die vaardighede waarmee kunstenaars toegerus word. ' $n$ Kunstenaar is in wese ' $n$ ondersoekende persoon wat deur middel van die kuns na 'n manier soek om uitdrukking te gee aan dít wat ontdek is. 'n Kreatiewe kunstenaar is iemand wat die moontlikhede raaksien om gewone en alledaagse idees in 'n nuwe skepping te omskep (Edwards 2008:39).

Uit navorsing in die Kunsgeskiedenis onderskei Grözinger (2002:170) veral vyf faktore wat kreatiwiteit op 'n direkte wyse beïnvloed, naamlik:

- Oorspronklikheid: Kunstenaars span hulleself in om dinge op 'n nuwe en oorspronklike wyse waar te neem.

- Buigbaarheid: Kunstenaars beywer hulle om nuwe insigte op so 'n manier oor te dra dat dit vir mense dikwels ongewoon mag voorkom.

- Sensitiwiteit: Kunstenaars erken dat 'n relevante probleem bestaan en gee deur middel van hulle kuns uitdrukking aan daardie realiteit.

- Vloeibaarheid: Die geykte wyse van kommunikasie vloei oor in 'n nuwe kommunikasiewyse deur middel van die kunswerk.

- Non-konformisme: Kunstenaars skroom nie om deur middel van hulle kuns 'n boodskap oor te dra nie, al gaan dit soms in teen die grein van die gemeenskap se gevoelens.

\section{Die eienskappe van kreatiewe denkers}

In die Kunsgeskiedenis word kreatiwiteit as'n onvoorspelbare saak beskou, omdat ou gewoontes en doenwyses deur die proses van kreatiewe denke getransformeer en selfs uitgedaag word (Stewart 2008:110). De Bono (1981:160) sluit hierby aan en toon dat kreatiwiteit ten doel het om nuwe idees te vind, of om addisionele nuwe insigte te skep. Kustenaars kan juis daarom selfs uit foute wat begaan word, kreatiewe idees vind om vanuit daardie doolhof 'n nuwe koers aan te dui. Kreatiewe denke wat in die ontdekking van nuwe insigte behulpsaam is, kan wel op 'n aktiewe wyse gestimuleer word sodat kunstenaars nie met arms gevou op inspirasie hoef te wag alvorens iets geskilder of gevorm word nie (Honour \& Flemming 2002:829). Arnason (1996:15) toon oortuigend aan dat mense (dus ook die hoorders van preke) se daaglikse lewe nie op 'n voorspelbare wyse verloop nie en juis daarom is kreatiewe kommunikasie 'n noodsaaklike middel om antwoorde op omstandighede te bied - omstandighede wat dikwels op 'n verrassende wyse oor mense se pad kom.

Stewart (2008:110-112) onderskei sewe kreatiewe denkeienskappe wat kreatiewe kunstenaars in hulle kunsbeoefening bemagtig:

- Ontvanklikheid: Kreatiewe kunstenaars is vir nuwe idees en ervarings ontvanklik en is bereid om na ander tipes oplossings vir bestaande probleme te kyk deur fyn te luister en waar te neem.

- Nuuskierigheid: Elke uitdaging en ongewone dinge wat 'n uitdaging bied, word met met nuuskierige erns benader en aangepak.

- 'n Verskeidenheid belangstellings: Indien hulle kennisbasis verbreed word, is kreatiewe kunstenaars optimaal in staat om breër verbandleggings te kan trek.

- Oplettendheid: Kreatiewe kunstenaars moet hulleself oefen om fyn na kleiner detail op te let. Hulle bemerk moontlikhede waarby ander mense bloot verbykyk.

- 'n Soeke na verbande: Kreatiewe kunstenaars is op soek na ooreenkomste tussen sake wat soms uiteenlopend mag voorkom.

- Oortuiging: Die bestaande insig en kennis dien as vertrekpunt waaruit nuwe insigte voortspruit. Hulle bevraagteken dikwels die heersende insig om by nuwe moontlikhede uit te kom.

- Kompleksiteit: Kreatiewe kunstenaars is suksesvol indien rasionele aspekte met intuïtiewe aspekte gekombineer word. Logika help hulle om sake te verwerklik, terwyl 'n intuitiewe aanvoeling hulle bemagtig om nuwe sake te ontdek. Kreatiewe kunstenaars word dikwels as komplekse mense beskou omdat rasionele sowel as intuïtiewe aspekte vir hulle belangrik is en die verkeerde persepsie bestaan dikwels dat kreatiewe kunstenaars se optrede weersprekend is.

\section{Kunsintelligensie: Linker- en regterbrein}

Edwards (2008:28-47) toon uit 'n kunsoogpunt die belangrikheid van visuele persepsie aan. Die ingewikkeldheid van waarneming sowel as die wonder hieraan verbonde, blyk uit die vakgebied van die Kunsgeskiedenis 'n merkwaardige 
saak te wees wat verdere besinning noodsaak. Cilliers (2004:208-209) is heeltemal korrek wanneer hy daarteen waarsku dat die onderskeid wat dikwels tussen linker- en regterbreindenkers gemaak word 'n oorvereenvoudiging van die werking van die menslike brein is. Hy stel dat die menslike brein uit agt neuro-kognitiewe sisteme bestaan wat moet saamwerk sodat 'n mens optimaal kan funksioneer. Nadenke oor die navorsing rakende die linker- en regterbrein in die Kunsgeskiedenis sal dus van waarde kan wees indien dit daarop dui dat die linker- en die regterhemisfeer van die brein in 'n organiese wisselwerking moet verkeer om optimale kreatiwiteit te bevorder (Edwards 2008:29; Stewart 2008:140).

Stewart (2008:29-36) toon die volgende sake ten opsigte van die linker- en regterhemisfeer van die brein aan:

- Die linkerhemisfeer oefen beheer oor die regterkant van 'n persoon se liggaam uit, terwyl die regterhemisfeer dieselfde doen ten opsigte van die linkerkant van die liggaam - 'n oorkruisbeweging dus.

- Taalvaardighede word met die linkerhemisfeer van die brein verbind en daarom word soms verkeerdelik na die regterhemisfeer as die ondergeskikte hemisfeer verwys.

- Albei hemisfere is gelyktydig met kognitiewe funksionering besig en dra op komplementêre wyse hiertoe by.

- Die twee hemisfere is albei besig om sensoriese inligting te versamel, maar die inligting word op verskillende maniere verwerk. Dit kan ook gebeur dat die dominante hemisfeer op 'n gegewe moment die beheer oorneem.

- Indien die regterhemisfeer die beheer oorneem, word groter klem op die verbeelding en die visuele geplaas. In die regterhemisfeer word ook nuwe kombinasies van idees geskep en inligting word sodanig verwerk dat die beeld of prent hiervan vir die persoon so duidelik in die gedagtes is, dat die uitroep aha! of eureka! dikwels geuiter word.

- Die regterhemisfeer van die brein plaas nie dinge in 'n numeriese of selfs 'n logiese volgorde nie, maar beskou die saak realisties. Die kompleksiteit van die saak soos dit op daardie moment daar uitsien, word gevisualiseer.

\section{Samevattende metateoretiese perspektiewe uit die vakgebied van die Kunsgeskiedenis}

- Kreatiwiteit het met die wyse waarop kunstenaars dinge waarneem, te make. Hierdie wyse is bepalend vir die manier waarop kunstenaars skeppend sal optree.

- Kreatiwiteit het ook met 'n vars en nuwe manier te make waarop die kontoere van die werklikheid beskryf word. Die doel van kreatiwiteit is om nuwe idees te vind sodat addisionele nuwe insigte geskep kan word.

- Die linker- en regterhemisfeer van die brein moet in ' $n$ organiese wisselwerking verkeer om optimale kreatiwiteit te bevorder.

- Kreatiewe denke help persone om opgewonde te raak oor die beeld wat hulle sien en verstaan.

\section{Metateoretiese perspektiewe oor kreatiwiteit vanuit die Sosiale Psigologie}

'n Besinning oor kreatiwiteit uit die hoek van die Sosiale Psigologie is veral noodsaaklik vanweë misverstande wat oor die funksionering van kreatiwiteit heers. Kreatiwiteit word dikwels verkeerdelik gesien as iets wat persone skielik te binne skiet of dat dit soos ' $n$ lig is wat in die donker by iemand aangeskakel word (Wood \& Wood 1999:277). Navorsing uit die Sosiale Psigologie toon oortuigend aan dat diepgaande kreatiwiteit dikwels juis die produk is van 'n intense studie van 'n doelgerigte nadenke en 'n indrigende belangstelling in iets (Swartz, De la Rey \& Duncan 2004:171). Bergh en Theron (2006:141) beklemtoon tereg dat kreatiwiteit nie ' $n$ eienskap is wat net op kunstenaars van toepassing is nie. Alle vakgebiede behoort kennis te neem van wat kreatiwiteit eintlik behels. In die volgende onderafdelings word sommige aspekte van kreatiwiteit bespreek.

\section{Die wese van kreatiwiteit}

Die kreatiewe proses behels die skepping van nuwe, oorspronklike en bruikbare idees (Bergh \& Theron 2006:140). Die skepping van nuwe idees bring mee dat kreatiwiteit 'n oplossing op probleme bied en juis daarom ruimte vir verandering skep (Wood \& Wood 1999:278). Weiten (1992:332) beklemtoon dat nuwe en kreatiewe denke wat soms vreemd mag voorkom, ook aanpasbaar moet wees. Kreatiwiteit moet dus op die situasie asook die probleem van toepassing wees. Woolfolk (2007:307) benadruk die feit dat daar ' $n$ onderskeid tussen konvergente en divergente denkers bestaan. Konvergente denkers benadruk die reëls en logika waardeur persone op grond van feite tot 'n logiese konklusie kom. Divergente denkers kom op grond van die inligting tot hulle beskikking tot verskeie oplossings (Louw \& Edwards 1998:313). Kreatiewe denkers is merendeels divergente denkers (Louw \& Louw 2007:237). Kreatiwiteit moet egter wel voortdurend gestimuleer en ingeoefen word en daarom speel kennis, buigsaamheid, motivering, volharding en sosiale ondersteuning in hierdie proses 'n belangrike rol (Woolfolk 2007:307).

Louw en Louw (2007:238) onderskei op grond van bogenoemde sake die volgende aksiestappe wat hulle belangrik ag in die stimulasie van kreatiwiteit:

- Stel persone aan die teenstrydighede en onsekerhede van hulle werklikheid bloot, omdat dit hulle forseer om na meer duidelikheid en sekerhede te soek.

- Gee aan persone die geleentheid om dít wat hulle geleer het met mekaar te deel.

- Respekteer altyd persone se vrae en onsekerhede. Indien iemand met die besef van onkunde gelaat word, plaas dit 'n demper op enige vorm van kreatiwiteit.

- Betrek persone so ver moontlik by dinkskrums en moedig hulle aan om idees te genereer.

- Probeer 'n omgewing skep wat kreatiwiteit stimuleer.

- Waak teen rigiede voorskriftelikheid.

- Stimuleer 'n gevoel van plesier en vreugde om dinge te doen eerder as om die klem op prestasies en beloning te plaas. 
- Skep 'n situasie waarin persone op 'n speelse wyse met hulle probleme omgaan. Dit impliseer dat die inspanning om met lewenswerklikhede om te gaan nie moeiliker gemaak moet word as wat dit reeds is nie.

- Stel kreatiewe persone aan mekaar voor.

Kreatiewe persone is volgens Weiten (1992:335) persone wat neig om meer intens vir hulself te dink en nie so maklik deur ander persone se opinies beïnvloed word nie. Hulle is ook meer verdraagsaam teenoor kompleksiteit en allerlei teenstellende gedagtes. Juis as gevolg van hierdie besef het kreatiewe persone die neiging om nie alles te wil oorvereenvoudig nie en hulle voel ook nie maklik deur onsekerheid bedreig nie (Bergh \& Theron 2006:141; Weiten 1992:335).

\section{Fases in die kreatiewe proses}

Bergh en Theron (2006:140-141) onderskei vier fases in die manifestering van die kreatiewe proses:

- Voorbereiding: In hierdie fase word nagedink of meer van die elemente geleer wat relevansie met die probleem toon. Die voorbereiding is dus 'n aksie wat bewustelik uitgevoer word terwyl die probleem of uitdaging in gedagte gehou word.

- Inkubasie: Tydens hierdie fase word die probleem of uitdaging en die feite wat hiermee verband hou vir 'n wyle eenkant geplaas, terwyl sekere assosiasies bewustelik gemaak word.

- Illuminasie of inspirasie: In hierdie fase dring die oplossing tot persone deur en insig begin posvat, omdat die idees samehangend en duidelik begin posvat.

- Verifikasie en verwerking: Die nuwe insig word in hierdie fase ondersoek en gefynkam om die finale fase te vorm.

Die proses van kreatiwiteit is dus 'n beweging wat vloei: vanaf assosiasie $>$ visualisering $>$ verbeelding $>$ probleem $>$ oplossing.

\section{Die verskil tussen kreatiewe en minder kreatiewe persone}

Volgens Bergh en Theron (2006:141) bestaan daar verskille tussen kreatiewe en minder kreatiewe persone.

- Kreatiewe persone is geneig om verskillende prosesse van kognitiewe verwerking in te span. In die primêre fase word beelde en assosiasies gebruik wat 'n nuwe kombinasie van idees voortbring. In die sekondêre fase val die klem op abstrakte en logiese denkpatrone. Minder kreatiewe persone neig om in die proses van verwerking te stagneer.

- Kreatiewe persone kan op meer as een saak konsentreer, terwyl minder kreatiewe persone geneig is om op slegs een saak te konsentreer.

- Kreatiewe persone neig om met 'n wyehoeklensbenadering te dink en sake meer oop en plat te maak eerder as om hiërargies hieroor te besin.

- Die psiogologiese reaksies van kreatiewe en minder kreatiewe persone verskil gedurende die kreatiewe proses wat in fases verloop. Minder kreatiewe persone is geneig om gespanne te raak sodat dit ' $n$ hindernis in die vorming van kreatiewe idees is.

- Kreatiewe persone se regterhemisfeer-ingesteldheid is bevorderlik vir verbeelding, intuïsie en visualisering.

\section{Samevattende metateoretiese perspektiewe uit die vakgebied van die Sosiale Psigologie}

Die volgende samevattende metateoretiese perspektiewe word gebied:

- Kreatiwiteit behels 'n skeppingsproses van nuwe, oorspronklike en bruikbare idees wat verandering moontlik maak.

- Kreatiwiteit is die produk van intense studie, gefokusde nadenke en diepgaande belangstelling in ' $n$ bepaalde saak.

- Kreatiwiteit moet voortdurend by persone gestimuleer word - ook by predikers. Doelgerigte inoefening in kreatiewe denke bevorder kreatiwiteit.

- Kreatiewe persone neig daarna om nie alles te wil oorvereenvoudig nie en hulle voel ook nie maklik deur onsekerheid bedreig nie.

- Kreatiewe kommunikasie vereis dat hoorders die geleentheid sal ontvang om hulle ontdekkings ook met mekaar te deel. Kreatiewe persone moet in kontak met ander kreatiewe persone bly, want daar bestaan ' $n$ interafhanklikheid in kreatiwiteit.

\section{Basisteoretiese perspektiewe ten opsigte van kreatiwiteit}

In hierdie onderafdeling word twee Skrifgedeeltes op 'n basisteoretiese wyse nader ondersoek, naamlik 2 Samuel 17 en Matteus 13:13-15 en 52. Vanweë die beperktheid van hierdie artikel val die aandag slegs op twee gedeeltes, terwyl die navorser besef dat daar heelwat ander gedeeltes is wat net so sentraal ten opsigte van die veld van ondersoek staan.

\section{Basisteoretiese perspektiewe ten opsigte van 2 Samuel 17}

In 2 Samuel 17 word vertel van Absalom se krisis ten opsigte van sy pa, Dawid, wat deur sy toedoen 'n voortvlugtige was (Barton 2002:273). Agitofel en Gusai was twee raadgewers wat Absalom met raad bedien het. Slegs Gusai se advies is egter aanvaar en Dawid se lewe is op grond van die kreatiwiteit in Gusai se advies gespaar (Wiersbe 2006:15). Dit is opmerklik dat die toespraak wat Gusai gelewer het so treffend was dat dit Absalom en sy manskappe oortuig het (Barton 2002:273). Evans (2004:242) onderskei in die kommunikasie van Gusai 'n duidelike oorredende boodskap. Manser (2010:403) bemerk op sy beurt dat Gusai in die eerste persoon meervoud, naamlik 'ons', praat. Hy betrek homself by sy hoorders. Agitofel het in die eerste persoon enkelvoud, 'ek', gepraat. Hiermee word 'n belangrike saak aangeroer, naamlik dat Agitofel in sy toespraak oor feite gepraat het en hom teenoor sy gehoor geplaas het (vgl. Adams 1982:44-45). Daarmee het hy sy dieper motief blootgelê, naamlik dat sy boodskap hom eintlik nie persoolik so diep raak nie (Evans 
2004:244). Agitofel se boodskap het getuig van dit wat hy vir Absalom wil doen en dit het wel instemming verwerf, maar is nie met ' $n$ besluit bekragtig nie en daarom was daar ook geen instemming daarmee nie (Manser 2010:404). Agitofel se goeie militêre strategie het juis as gevolg hiervan verlore gegaan. Gusai se advies het by Absalom en sy raadgewers byval gevind.

Wiersbe (2006:16-20) toon die kontras tussen Agitofel en Gusai se gesprekke op die volgende wyse aan:

- Gusai se gesprek is drie maal langer as dié van Agitofel, wat homself in sy toespraak tot die feite beperk het. Gusai het moeite gedoen om beelde en prentjies vir sy hoorders te skilder en juis daarom was sy toespraak ook langer. Absalom en sy manskappe het buitendien tyd nodig gehad om hierdie beelde wat Gusai geskets het, te visualiseer.

- Agitofel se toespraak het 'n tipiese linkerhemisfeeraanslag gehad, terwyl Gusai 'n tipiese regterhemisfeeraanslag in sy toespraak geopenbaar het.

- Absalom het bloot gehoor wat Agitofel aanbeveel het, maar hy kon dít wat Gusai aanbeveel het hoor, sien en ook 'n aanvoeling daarvoor verkry.

- Alhoewel Gusai se toespraak tekortkomings ten opsigte van militêre kundigheid gehad het, was dit tog oortuigend.

- Agitofel het vier maal in sy toespraak (2 Sam 17:1-14) gesê ' $\mathrm{ek} \mathrm{sal'.} \mathrm{Daarmee} \mathrm{het} \mathrm{hy} \mathrm{die} \mathrm{fokus} \mathrm{op} \mathrm{homself} \mathrm{laat}$ val as 'n outoritêre figuur wat oor 'n logiese plan beskik het wat ook op 'n militêre wyse sin gemaak het.

- Agitofel se toespraak het aan Absalom 'n padkaart gebied, terwyl Absalom eintlik 'n oorsig gevra het. Die militêre presiesheid en die logiese denkpatroon was nie oortuigend nie. Agitofel kon nie Absolom en sy manskappe die roete laat sien wat hulle moes volg nie.

- Gusai het sy woorde sodanig gebruik dat dit prente geskilder het (2 Sam 17:5-14). Hy het vergelykings en metafore gebruik, byvoorbeeld:

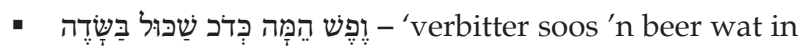
die veld van haar kleinties beroof is'

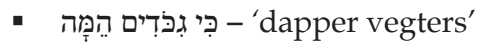

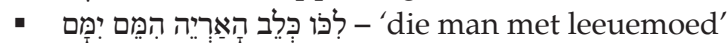

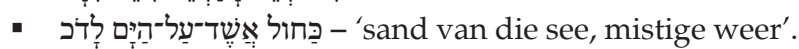

- Met hierdie beelde en prente is die ore van Absalom en sy manskappe as 't ware in siende oë getransformeer sodat dit kon waarneem. Absalom en sy manskappe kon hulle indink en hulself verbeel wat alles sal gebeur indien hulle nie Gusai se advies aanvaar nie.

- Gusai het Absalom en sy manskappe sodanig deur sy toespraak bemagtig dat hulle nie oorheersend met die linkerhemisfeer gedink het nie, maar eerder met die regterhemisfeer.

- Gusai het met sy toespraak bewys dat hy daarvan bewus was dat persone in terme van beelde en prentjies dink.

- Gusai was ook daarvan bewus dat woorde en beelde meewerk om die wêreld binne die hoorders en die wêreld rondom die hoorders te oorbrug.
- Die verskil in Agitofel en Gusai se kommunikasie kom daarop neer dat eersgenoemde informasie wou uitdeel, maar laasgenoemde wou sodanig kommunikeer dat dit indring.

- Gusai het met sy kommunikasie in die verbeelding van Absalom en sy manskappe beelde opgehang wat aan almal goed bekend was. Dit was dus nie vir hom nodig om 'n fantasiewêreld te probeer skep nie.

- Gusai se woordgebruik het aan lewensveranderende beelde geboorte gegee, terwyl Agitofel se konsepte en feite steriel was. Die metaforiese taalgebruik van Gusai het ten doel gehad om sy hoorders sekere dinge te laat sien en ervaar.

In 2 Samuel 17:14b word die optrede van Gusai duidelik met God se werking verbind om God se teenwoordigheid ook in die toespraak van Gusai te benadruk (Evans 2004:243). Die uitdrukking dat dit die Here was wat Agitofel se raad verydel

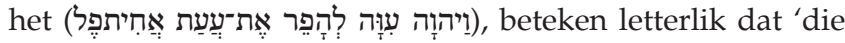
Here die verydeling beveel het' (Manser 2010:402). Hierdeur word die gedagte van teonome resiprositeit aan die orde gestel. Die verhouding tussen God en die mens word in die Praktiese Teologie dikwels met die term teonome resiprositeit omskryf. Dit is 'n begrip wat oorspronklik deur Van Ruler (1969:181) gebruik is. Met resiprositeit bedoel Van Ruler die erkenning dat God alles op 'n teonome manier gee, maar sodanig dat Hy persone aan die werk sit. Hieruit word die afleiding gemaak dat alhoewel God Gusai as ' $n$ instrument gebruik het om Absalom tot 'n val te bring, dit steeds vir Gusai noodsaaklik was om sy oorredende boodskap op 'n kreatiewe wyse te bring. Oorredende boodskappe (prediking) is daarom ook met die vraag gemoeid wat die prediker wil hê sy hoorders moet na afloop van die boodskap ervaar (Ortberg 2012:27).

\section{Basisteoretiese perspektiewe ten opsigte van die gelykenisse van Jesus met besondere verwysing na Matteus 13:13-15, 52}

Wiersbe (2006:159) toon aan dat Jesus dikwels tydens sy aardse lewe in stryd was met die Fariseërs, nie net oor die inhoud van sy verkondiging nie, maar veral oor die wyse waarop Hy dit gedoen het. Jesus het die vermoë om mense van alle stande en omstandighede te onderrig, juis vanweë die feit dat Hy die mens se verbeelding kan aangryp (Manser 2010:1434). Floor (2007:2) toon die onuitputlike bron van Jesus se onderrig aan met besondere verwysing na Matteus 13:52. In Matteus 13:52 is daar sprake van die skatkamer ( $\tau$ ov

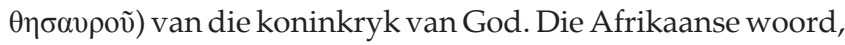
tesourie, is van $\theta \eta \sigma \alpha v \rho o \tilde{~ a f g e l e i ~(F l o o r ~ 2007: 2) . ~ J e s u s ~ n o e m ~ d i e ~}$ skatte in die tesourie van die koninkryk van die hemel, die ou

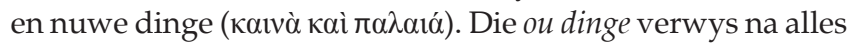
wat in die wet deur die profete verkondig is, terwyl die nuwe dinge na die boodskap verwys wat in Christus 'n realiteit geword het. Daar kan dus met reg gesê word dat die Nuwe Testament (nuwe dinge) in die Ou Testament aanwesig is en dat die Ou Testament (ou dinge) in die Nuwe Testament tot openbaring kom (Floor 2007:2). 
Smit (1987:23) onderstreep die gedagte dat 'n gelykenis net een spits, skopus of blikrigting het. Die opmerklike van hierdie skopus is dat daarin vir 'n spel van kreatiewe en verbeeldingryke assosiasies ruimte geskep word (Smit 1987:23). Dit wil dus voorkom asof daar in die ou en nuwe dinge wat Jesus se dissipels as sy navolgers verkondig het, altyd sprake sou wees van 'n onuitputlike bron waaruit gepreek kon word. Hierdie verkondiging moes egter ook op 'n kreatiewe wyse sekere beelde aangaande God se koninkryk by die hoorders oproep. Hierdie ou en nuwe dinge vereis die reaksie om te sien en te luister. Van der Walt (1991:101) plaas die klem daarop dat Jesus in die gebruik van gelykenisse die opvoedkundige beginsel van ' $n$ beweging vanaf die bekende na die onbekende eerbiedig. Daardeur word die geestelike lewe van die hoorders aan die hand van 'n toneel uit die alledaagse lewe geillustreer.

Wiersbe (2006:160-165) bemerk in sy navorsing die volgende belangrike gedagtes aangaande kreatiewe onderrig uit Jesus se gelykenis oor die saad:

- Jesus wend gelykenisse aan om die mense van sy tyd se aandag kreatiewelik op die inhoud van sy onderrig te vestig.

- Elke Skrifgeleerde wat 'n leerling in God se koninkryk word, is soos 'n huiseienaar. Hiermee word die verband gelê tussen die studie van God se Woord (die Skrifgeleerde), die beoefening hiervan (die leerling) en om dit met ander mense (die huiseienaar) te deel. Opregte Skrifgeleerdes leef eers dít wat hulle verkondig persoonlik en juis daarom het hulle as huiseienaars ook iets onuitputbaars om met ander mense te deel.

- Om as huiseienaar met ander mense die ou en nuwe dinge te deel, bring mee dat nuwe dinge in die ou dinge ontdek word en dat nuwe toepassings in die ou dinge gevind word. Daar word dus met 'nuwe' ore gehoor en met 'nuwe' oë gesien.

- Jesus se onderrig deur middel van gelykenisse was 'n beeld (prent) wat Hy in 'n spieël omskep het om ook 'n venster te word. Die beeld van ' $n$ alledaagse verhaal is aan die hoorders voorgehou, iets waarmee almal kon assosieer. Terwyl die hoorders die gelykenis aangehoor het, het die gelykenis ook iets geword waarin hulle hulself bemerk het en van hulle eie lewe bewus geraak het. In die derde plek moet gelykenisse ook'n herkenning van God se boodskap asook die hoorders se eie konkrete lewensomstandighede meebring. Op hierdie wyse werk gelykenisse van die sien en die hoor na insig wat uiteindelik op visie uitloop.

- Die gebruik van beelde wat die hoor van die Woord in beelde in die hoorders se lewe omskep, staan sentraal. Alledaagse gebeurtenisse word in boodskappe met 'n hemelse betekenis omskep.

Macdonald (2012:63) bemerk in Jesus se gelykenisse 'n erns om te preek, maar ook 'n duidelikheid, selfs al het die mense geestelik doof en blind geword. Geen prediker hoef dus ooit te poog om God se Woord relevant te maak nie, aangesien dit reeds relevant is. Die taak van die predikers is om die relevansie van die Woord deur hulle prediking aan die hoorders te wys (Larson 2012:62).

\section{Samevattende basisteoretiese perspektiewe ten opsigte van kreatiwiteit}

Op grond van bogenoemde uiteensetting word die volgende perspektiewe gebied:

- Die uitgangspunt van kreatiewe prediking berus op die feit dat die predikers in hulle preeklewering hulself as deel van die gemeente moet beskou, sodat dit nie 'n boodskap uit die hoogte word met die klem op blote kennisoordrag nie.

- Kreatiewe preekoordrag impliseer dat die inhoud van die prediking allereers die predikers moet raak sodat dit uit hulle preeklewering kan blyk.

- Kreatiewe prediking help hoorders om die boodskap van die preek te visualiseer. Daarom is die aanwending van beelde en metafore besonder funksioneel.

- Predikers moet hulself in kreatiewe prediking inspan om op die linker- sowel as die regterhemisfeer van hoorders se denke in te speel.

- Toepaslike woordgebruik is van onskatbare waarde in kreatiewe prediking.

- God gebruik die prediking as 'n instrument in die hoorders se lewe, maar die predikers moet hulself inspan om hierdie Woord op 'n kreatiewe wyse oor te dra.

- Die inhoud van kreatiewe prediking is die skatkamer van ou en nuwe dinge uit die Woord wat kreatief ontsluit moet word.

- Kreatiewe prediking roep verbeeldingryke assosiasies in die hoorders se lewe op.

- Kreatiewe prediking skilder aan die hoorders die lewensveranderende noodsaak van God se Woord in hulle unieke omstandighede.

\section{Praktykteoretiese perspektiewe ten opsigte van die rol van preekgesprekke as verryking van kreatiwiteit}

In die Praktiese Teologie is al meermale indringende navorsing gedoen oor wat dit van predikers in die verskillende stadiums van preekvoorbereiding verg om kreatief te kan preek. McClure (1995:7) benadruk in hierdie opsig die rol van 'collaborative preaching' in 'n poging om die hoorders in die ontdekking van die boodskap van die teks saam te neem. Cilliers (1998:130) benadruk die rol van die predikers as skeppende persone onder die prediking en wys daarop dat die indrukke van die hoorders vooraf asook na afloop van die prediking van kardinale belang is. Hy pleit vir 'n dialoog tussen die preekstoel en die kerkbanke - wat deur McClure (1995:8) 'n 'bemagtigende optrede' genoem word. McClure (1995:20-24) benadruk die volgende aspekte hieromtrent:

- Van aangesig-tot-aangesig-verhoudings tussen die predikers en die hoorders.

- Die predikers moet die hoorders toerus om ook hulle eie 
verantwoordelikheid ten opsigte van die belangrikheid van die prediking te begryp. Tussen die wêreld van die teks en die wêreld van die gemeente moet 'n duidelike verband gelê word.

- 'n Voorbeeld van die verskerping van die hoorders se kreatiewe deelname aan die prediking is die 'rondetafel-benadering' ten opsigte van die prediking. Hierdie benadering bring mee dat die verwagtings van hoorders ten opsigte van die prediking vroeër uitgespreek word, sodat die prediking onder die erediens 'n groter en meer diepgaande realiteit van inspirasie voortbring. Die hoorders se vooraf-deelname aan 'n preekgesprek bring mee dat die hoorders ook hulle eie insigte en stemme onder die prediking kan herken. Preekgesprekke na afloop van die erediens stel die predikers en die hoorders in staat om die aha-besef van verwondering oor dít wat die teks van hulle vra, met mekaar te deel.

Opgrond van dienavorsing in hierdieartikel asook dieaksente wat aangetoon is, kan die volgende praktykteoretiese merkers by wyse van toespitsing gebied word om die kreatiwiteit van die prediking deur middel van preekgesprekke (ook bekend as die ekklesiale diskoers) te verhoog:

- Predikers kan dit oorweeg om reeds vroeg in die week die eksegetiese en hermeneutiese lyne van die teks aan die gemeente (of 'n werkgroep uit die gemeente) beskikbaar te stel. Die prediker se stem as hoorder onder die hoorders word sodoende deur die lidmate gehoor asook die duidelike eksegetiese begronding wat die eerste en vername stap in kreatiewe preekvoorbereiding vorm. Hierdeur word die retoriese betekenis en die impak van die genre vroeg reeds aan die hoorders oorgedra.

- Die werking van die Heilige Gees wat predikers kreatief maak, moet altyd op die voorgrond staan. God alleen kan iets skep wat totaal en al nuut is. Kreatiewe predikers en kreatiewe hoorders wend egter die werklikheid van die teks en die werklikheid van hulle konteks sodanig aan dat dit deur die werking van die Gees nuut en vars word. Die Heilige Gees gebruik daarom ook eg menslike faktore soos die predikers, die predikers se eksegese, die predikers se toepassing asook die predikers se woordkeuse. Die predikers moet in hierdie fase oop wees vir alle impulse wat die teks en die gemeente voortbring. Dit veronderstel dat die preek nooit oorhaastig voorberei mag word nie. Predikers moet genoeg geleentheid hê om die preek te oordink (inkubasie). Die vooraf-preekgesprek stel die hoorders in staat om vooraf ' $n$ wye verskeidenheid sake te oordink.

- Geleenthede word gebied waar groepe persone die predikers in die preekgesprekke ontmoet om deur middel van hulle bydraes en stemme die konkrete werklikhede van die hoorders binne die gemeente met die predikers te deel. Sodoende word die prediking van abstraksie bevry. Meer as een aspek word by hierdie gesprekke betrek, wat die moontlikhede vir 'n nuwe visie verhoog. Moontlike aspekte wat betrek kan word, is byvoorbeeld die dienswerk van die gemeente na binne en buite, die etiese implikasies van die boodskap van die teks op die daaglikse lewenswerklikheid van die hoorders en selfs ook 'n verstelling van die bepaalde bedieningstrategie wat tans gevolg word.

- Predikers verwerk hulle eie insigte tesame met dit wat hulle van die lidmate in die vormgewing van die preek verkry het. Cilliers (1998:139) wys daarop dat 'n mens slegs $10 \%$ van die dinge onthou wat jy lees, $20 \%$ van dit wat gehoor word, $60 \%$ van dit wat hulle self gesien en onder woorde gebring het en $90 \%$ van dit wat self ontdek is. Kreatiwiteit in die prediking word aansienlik verhoog indien die hoorders saam op weg geneem word in die preekvoorbereiding. Indien die hoorders die ruimtes van die teks self deur middel van 'n preekgesprek ontdek en wanneer hulle ook deel in die handeling wat die prediking uitmaak, bring dit 'n kreatiewe visie op dít wat die Woord van elkeen eis om te doen.

- Predikers besin in die besonder oor die kreatiwiteit van die liturgie onder die erediens en hoedanig die linkersowel as die regterhemisfeer van die brein ingespan kan word sodat die erediens as sodanig aan die hoorders die weg toon om lewensveranderend in die liturgie van die lewe te leef. Die amen aan die einde van die preek moet nie op die einde van die preek dui nie, net so min as wat die amen aan die einde van die erediens op die einde dui. Dit moet eerder op 'n nuwe en kreatiewe begin of voortgang daarvan dui. Kreatiewe hoorders is hoorders wat, aan die hand van die duidelike beelde wat die prediking oproep, met die linker- sowel as die regterhemisfeer van die brein optimaal begryp.

- Predikers maak in die preekvorming moeite daarmee om deur middel van woordkeuse, beelde, die styl van die prediking en die aanwending van metafore doelbewus sekere beelde en prente by die hoorders op te roep sodat hulle ook 'n duidelike beeld kan hê van wat God van hulle verwag. Predikers moet hulle woordeskat daarom doelbewus uitbou. Deur die uitbreiding van die woordeskat verbreed die predikers se horison ook verder (Wiersbe 2006:298). Die hoorders moet na aanleiding van die preek duidelik kan visualiseer wat die teks van hulle eis en in hierdie proses is die predikers op woorden taalgebruik aangewese. Deur keurige en toepaslike taalgebruik moet die beeld van die teks ' $n$ venster word waardeur gekyk word sodat die hoorders in die spieël van die teks hulself duidelik kan herken.

- Die waarde van sodanige voorafgesprekke lê ongetwyfeld opgesluit in die feit dat die predikers deur middel van die preekgesprekke in kontak met ander kreatiewe persone kom. Kreatiwiteit word in hierdie proses gestimuleer. Die predikers se kreatiwiteit moet gevoed word deur gereeld te lees, gefokus te luister en gereeld met kreatiewe persone te kommunikeer (Wiersbe 2006:295).

- Kreatiewe preekgesprekke verryk nie slegs die preekinhoud nie, maar ook die kommunikasie. Kreatiewe voorafpreekgesprekke kan verhoed dat die predikers op 'n eensydige wyse met 'n blote informasie-oordrag betrokke raak.

- Predikers maak tydens die preekvoorbereiding moeite daarmee om hulle van die gemaksones te vergewis waarin so maklik verval kan word. Gemaksones en gewoontes in die preekmaakproses is dikwels ' $n$ bedreiging vir kreatiwiteit. 
- Na afloop van die prediking kan preekgesprekke moontlik by wyse van 'n samekoms na die eredienste geskied. Tydens hierdie gesprekke klaar die hoorders dit vir hulself uit hoedanig die spesifieke preek veranderend in hulle lewe te werk gegaan het. Die predikers word hierdeur in staat gestel om leemtes in die preek te ondervang, verkeerde persepsies reg te stel en dit skep ook die ruimte om in 'n volgende preek dieper op hierdie aspekte in te gaan, wat verdere besinning nodig maak. Kreatiewe prediking vorm sodoende die ingangsportaal tot 'n ronde-tafelkommunikasie wat op die Woord van God gegrond is en deurlopend plaasvind. Hierdie gesprekke moet altyd duidelik op die lewensveranderende aard en die bedoeling van die Woord gefokus bly.

- Kreatiewe prediking het ook ten doel om die ander aspekte van die gemeentelike bediening soos die leitourgia, die diakonia, die koinonia en die marturia te verryk. Sodoende word die ou en nuwe dinge uit die tesourie (skatkamer) van God se Woord geneem sodat die werklikheid vir die hoorders nuut gemaak word.

\section{Slot}

Geen bedienaar van die Woord kan ooit daarop roem dat daar in die prediking iets verkondig word wat nog nooit vantevore genoem is nie. Dit neem egter nie die verantwoordelikheid van predikers weg om dit wat gesê word op 'n vars en kreatiewe wyse te stel nie. 'n Vars aanslag neem immers die kreatiewe denke van die hoorders in ag. Hierdie artikel pleit daarvoor dat die predikers op 'n oorspronklike en kreatiewe wyse in die preekvoorbereiding besig sal wees. Benewens die kreatiewe teks waarmee gewerk word, is daar ook kreatiwiteit in preekgesprekke opgesluit. Onder leiding van die Heilige Gees moet die predikers sodanig lees, hoor, praat en skryf dat die preeklewering werklik uit die ou dinge tegelyk nuwe dinge voortbring en dat die ou dinge in die nuwe dinge duidelik herkenbaar sal wees. Kreatiewe boodskappe werk oorredend, omdat dit persone se verbeelding aangryp. Kreatiewe preke is funksioneel daarin om die ore in vérsiende oë te transformeer wanneer na preke geluister word.

\section{Erkenning \\ Mededingende belange}

Die outeur verklaar dat hy geen finansiële of persoonlike verbintenis het met enige party wat hom nadelig kon beïnvloed het in die skryf van hierdie artikel nie.

\section{Literatuurverwysings}

Adams, J.E., 1982, Preaching with purpose, Zondervan, Michigan.

Arnason, H.H., 1996, A history of modern art, Thames \& Hudson, London.

Avery, W.O. \& Grobbel, A.R., 2009, 'A reader on preaching', in J. Astley \& L.J. Francis (eds.), The Word of God and the words of the preacher, pp. 266-277, Ashgate, Surrey.

Barton, D., 2002, 'Good news from the first Christians', in D. Alexander \& P. Alexande (eds.), The Lion handbook to the Bible, pp. 269-274, Lion Hudson, London.

Bergh, Z. \& Theron, A., 2006, Psychology in the work context, Oxford University Press, Cape Town.

Brueggemann, W., 2009, 'A reader on preaching', in D. Day, J. Astley \& L.J. Francis (eds.), An imaginative or explorations in Practical Theology and Empirical Theology, pp. 51-65, Ashgate, Surrey.
Cartledge, M.J., 2003, Practical theology-charismatic and empirical perspectives, Paternoster, London.

Cilliers, J.H., 1998, Die uitwysing van God op die kansel: Inspirerende perspektiewe op die prediking -om God te sien en ander te laat sien, Lux Verbi, Kaapstad.

Cilliers, J.H., 2004, The living voice of the gospel: Revisiting the basic principles of preaching, Sun Press, Stellenbosch.

Cilliers, J.H., 2009, 'Skrifbeskouing en oorredingsretoriek: Perspektiewe op performatiewe prediking', Acta Theologica (1), 1-16.

Craddock, F.B., 1985, Preaching, Abingdon, Nashville.

De Bono, E., 1981, Practical thinking, Penguin Books, New York.

De Gruchy, J.W., 2011, 'The humanist imperative in South Africa', South African Journal of Science 107(7/8), Art. \#804.

De Wet, F.W., 2011, 'Die noodsaak daarvan om meta-teoretiese vertrekpunte ten opsigte van werklikheidsbeskouing in prakties-teologiese wetenskapsbeoefening uit te spel', In die Skriflig 45(1), 1-24. http://dx.doi.org/10.4102/ids.v45i1.2

Edwards, B., 2008, Drawing on the right side of the brain, Harper-Collins, London.

Engemann, W., 2002, 'On man's re-entry into his future: The sermon as creative act, Studia Homiletica 4, 25-50.

Evans, M.J., 2004, 'The message of Samuel', in A. Motyer, J. Stott \& D. Tidball (eds.), The Bible speaks today, pp. 1-283, InterVarsity, Nottingham.

Firet, J., 1987, Spreken als een leerling: Practisch theologische opstellen, Kok, Kampen.

Floor, L., 2007, Uit die skatkamer van die koninkryk, Boekuitgewers, Pretoria.

Gordon, T.D., 2009, Why Johnny can't preach: The media have shaped the messengers, R.R. Publishers, New Jersey.

Grözinger, E., 2002, Preaching as a lifelong process of creating perspectives, Ashgate, Surrey. (Studia Homiletica).

Honour, H. \& Flemming, J., 2002, A world history of art, Laurence King Publishers, London.

Joubert, S., 2003, God se roepstem en hoe moderne pelgrims daarop antwoord, Christelike Uitgewersmaatskappy, Vereeniging.

Koopman, N., 2010, 'Calvin and public holiness in Africa', NGTT Nederduitse Gereformeerde Teologiese Tydskrif 51, Supplementum 1, Teologie 150+ en Calvyn 500, 379-389.

Larson, C.B., 2012, 'Prophetic preaching', in F. Chan, J. Ortberg, T. Keller, M. Buchanan, A.G. Lotz, M. Driscoll \& K. Ulmer (eds.), What all good preachers do, pp. 59-67, Hendrickson, Massasuchets.

Long, T.G., 2005, The witness of preaching, Westminster John Knox, Louisville.

Long, T.G., 2009, Preaching from memory to hope, Westminster John Knox, Louisville.

Louw, D. \& Edwards, D., 1998, Sielkunde: 'n Inleiding vir studente in Suider-Afrika, Heinemann Voortgesette Onderwys, Sandton.

Louw, D. \& Louw, A., 2007, Die ontwikkeling van die kind en die adolessent, ABC Drukkers, Bloemfontein.

Macdonald, G., 2012, 'Inspirational preaching', in J. Piper, G. Macdonald, S. Chapman, B. Wilkerson, H. Robinson, J. Arthurs, J. Ortberg \& C.B. Larson (eds.) Soul-deep preaching, pp. 51-63, Hendrickson, Massachusetts.

Manser, M.H., 2010, The new Matthew Henry commentary, Zondervan, Grand Rapids.

McClure, J.S., 1995, The roundtable pulpit, Abingdon, Nashville.

Mitchell, H.H., 2009, 'A reader on preaching', in D. Day, J. Astley \& L.J. Francis (eds.), African-American preaching: The future of of a rich tradition, pp. 195-204, Ashgate, Surrey.

Ortberg, J., 2012, 'Inspirational preaching', in J. Piper, G. Macdonald, S. Chapman B. Wilkerson, H. Robinson, J. Arthurs, J. Ortberg \& C.B. Larson (eds.), Authentic inspiration, pp. 19-27, Hendrickson, Massachusetts.

Osmer, R., 2010, 'Practical Theology: A current international perspective, Annual Conference for the society for Practical Theology in South Africa', January 2010.

Pieterse, H.J.C., 2001c, Prediking in 'n konteks van armoede, ABC Press, Pretoria.

Piper, J., 2012, 'Inspirational preaching', in J. Piper, G. Macdonald, S. Chapman, B. Wilkerson, H. Robinson, J. Arthurs, J. Ortberg \& C.B. Larson (eds.), The supremacy of God in preaching, pp. 1-9, Hendrickson, Massachusetts.

Reierson, G.B., 1988, The art in preaching: The intersection of theology, worship and preaching with the arts, University Press of America, New York.

Robinson, H.W., 2001, Expository preaching: Principles and practice, Baker House, Grand Rapids.

Smit, D.J., 1987, 'Riglyne vir prediking oor die gelykenisse en wonderverhale', in C.W. Burger, D.J. Smit \& B.A. Müller (reds.), Die prediking van die gelykenisse in die evangelies, bl. 11-26, N.G. Kerk-Uitgewers, Kaapstad.

Stewart, M., 2008, Launching the imagination, McGraw Hill, New York.

Stott, R.W., 1996, Your mind matters, InterVarsity, Leicester.

Swartz, L., De la Rey, C. \& Duncan, N., 2004, Psychology, An introduction, Oxford, New York. 
Troeger, T.H., 2007, 'Seeing visions and dreaming dreams: The imaginative power of preaching hope', in C. Vos, L.L. Hogan \& J.H. Cilliers (eds). Preaching as a language of hope, 73-80, Ashate, Surrey. (Studia Homeletica 6.)

Tubbs-Tisdale, L., 2010, Prophetic preaching - a pastoral approach, Westminster John Knox, Louisville.

Van der Walt, T., 1991, Openbaringsgeskiedenis van die Nuwe Testament, Sentrale Publikasies, Potchefstroom.

Van Ruler, A.A., 1969, Theologisch werk, Deel 1, Callenbach, Nijkerk.

Vos, C.J.A., 1996, Die volheid daarvan: Homiletiek uit'n hermeneuties-kommunikatiewe hoek, RGN, Pretoria.
Vos, C.J.A., 2007, 'Preaching the language of hope', in C. Vos, L.L. Hogan \& J.H. Cilliers (eds.), Preaching as a language of hope, pp. 11-28, InterVarsity, Nottingham. (Studia Homeletica 6).

Weiten, W., 1992, Psychology, themes and variations, Brooks \& Cole, California.

Wiersbe, W.W., 2006, Preaching and teaching with imagination, Baker, Grand Rapids. Wood, S.E. \& Wood, E.G., 1999, The world psychology, Allyn \& Bacon, Boston.

Woodley, M., 2012, 'Inspirational preaching', in J. Piper, G. Macdonald, S. Chapman, B. Wilkerson, H. Robinson, J. Arthurs, J. Ortberg \& C.B. Larson (eds.), Preaching with childlike wonder, pp. 125-133, Hendrickson, Massachusetts.

Woolfolk, A., 2007, Educational psychology, Pearson, Boston. 